\title{
Könyvismertetés: Konyhanyelven a mellrákról - táplálkozási útmutató az érintetteknek
}

\author{
Book review: Simply about breast cancer - dietetic guidance for the affected
}

\begin{tabular}{ll}
\hline Ismertető: & Moharos Melinda \\
Ismertetett könyv: & Arató Györgyi: Konyhanyelven a mellrákról. Budapest, PrintPrix Nyomda, Szerzői \\
& kiadás, 2020. \\
Kulcsszavak: & kemoterápia; mellrák; diéta; emlődaganat; dietetikus \\
Keywords: & chemoterapy; breast cancer; diet; dietitian
\end{tabular}

Beküldve: 2021. 06. 30., doi: 10.24365/ef.v62i3.6737

Az emlődaganat az egyik leggyakoribb daganatos megbetegedés hazánkban, nagyjából minden 9-10. nő érintett lesz benne élete során. Az érintetteknek laikusként nagyon nehéz megfelelően tájékozódni az új helyzetben, hiszen felfoghatatlanul sok információval találkoznak, ezek jelentős része pedig nemhogy nem segít, hanem fokozott kockázatot jelent az állapotukra nézve. Egy dietetikus, aki maga is daganatos volt, könyvbe rendszerezte az evidence-based (bizonyítékokon alapuló) információkat, kipróbált gyakorlati tippeket és recepteket, amelyek segítenek mindig az adott terápiához és aktuális állapothoz igazítani az életmódunkat, táplálkozásunkat.

\section{SZAKMAISÁGGAL A TÉMÁRÓL EGY ÉRINTETTŐL}

A szerző Arató Györgyi dietetikus, egészségügyi szaktanár, miután maga is érintett lett, alaposan elmélyedt a mellrákra vonatkozó hazai és nemzetközi ajánlásokban, valamint a saját maga által is kipróbált, különböző táplálkozási „praktikák”ban. Már az előszóban tisztázza, hogy önmagában a táplálkozás nem fogja meggyógyítani a rákot, azonban a megfelelő étrenddel, életmódbeli "trükkökkel" jelentősen enyhíthetők az esetleges mellékhatások, gyorsabb lehet a gyógyulás és a regeneráció. Az évek alatt szerzett információkat, tapasztalatokat összegyuujtötte és - egészségügyi szakemberként - szakmai szemmel könyv formájában rendszerezte.

\section{KONYHANYELVEN AZ ÉRINTETTEKNEK}

A kötet az átlagemberek számára készült. A szöveg jól érthető, orvosi kifejezésektől mentes, valóban az ételek nyelvére van lefordítva, receptekkel, mintaétrenddel kiegészítve, hogy a gyakorlatban, a mindennapi életben is hasznos legyen a mellrákban szenvedők számára.

A könyv első felében a szakirodalom és a szerző saját tapasztalatai alapján a különböző terápiákhoz kapcsolódó táplálkozási ajánlások, konkrét, hasznos tippek olvashatók, a második fele pedig mintarecepteket tartalmaz. Mivel a kezelések, valamint az ezekkel járó stressz egyaránt okozhatnak fogyást és hízást, így a hagyományos recepteknek energiadús és energiaszegény változata is megtalálható a könyvben. Kiemelt szempont volt, hogy az ételek egyszerűek, gyorsan elkészíthetők legyenek. Számos gyakorlati tippet is kap az olvasó, például hogyan lehet az adott adag ételt dúsítani (pl. tápszerekkel), vagy éppen energiaszegényen elkészíteni.

A kiadvány mégsem receptkönyv elsősorban, hanem inkább megbízható információkat és komplex szemléletmódot közvetítő kötet. Olyan alapismeretekkel gazdagít, amelyek alapján megfelelő kritikával kezelhetők az interneten vagy épp az orvosi váróban a betegek közt terjedo "városi legendák", tévhitek. Az olvasó a könyv segítségével olyan gyakorlati tudásra tehet szert, amellyel a már megszokott, családi recepteket is át tudja alakítani az aktuális egészségi, tápláltsági állapotának megfelelően. 
Az onkológiai és táplálkozás-élettani részeket $D r$. Horváth Zsolt PhD klinikai onkológus és Dr. Biró Lajos PhD egyetemi docens lektorálta.

\section{TÁPLÁLKOZÁSI TIPPEK A TERÁPIÁK SORÁN}

A könyv gyakorlatiasan vezeti végig az olvasót az egyes terápiákon. Bevált életmódi tanácsokat ad, például hogyan készüljünk fel a kemoterápiára, mi minden legyen otthon, olyan szempontok szerint, amire a betegek általában nem szoktak gondolni, és az orvosoknak pedig érthető módon nincs kapacitásuk ilyen mélységben foglalkozni ezzel a témával.

Sorra veszi az összes lehetséges mellékhatást, és kipróbált, működő tippeket ad arra, hogyan lehet ezeket enyhíteni. Időrendben rendszerezi az információkat: mit tegyünk, mire figyeljünk a terápia előtt, két kemoterápia közben és a kezelés után. Hasonlóan alaposan kalauzol végig a mútétek, a sugár- és az antihormon-terápia kérdéskörén is.

Daganatos betegségben mindig kihívás a megfelelő testtömeg elérése és/vagy megtartása. Nemcsak a fogyás, de gyakran a nem várt hízás (pl. az antihormon-terápia miatt) még további stresszt és frusztrációt is okoznak. Mindkét esetben jól felépítve magyarázza el a szerző, csodadiéták nélkül, hogy mely esetben mire kell nagyon odafigyelni, melyik alapanyagot mire cseréljük le ésatöbbi. Az ételek minden esetben egyszerü hozzávalókból állnak, gyorsan elkészíthetők, könnyen emészthetők, emellett finomak is. Külön fejezet tartalmazza a tápszerek megismertetését és gyakorlati használatát (amennyiben szükséges az ételek dúsítása).

\section{KIEGÉSZÍTŐ TÉMÁK}

Nem jellemző, hogy szóba kerül a daganatos betegek diétái során, de az élelmiszerbiztonság kiemelten fontos, mert a legyengült szervezet sokkal sérülékenyebb, sokkal érzékenyebb az esetleges fertőzésekre, erről is készült külön fejezet.

$A z$ étrendkiegészítők és alternatív terápiák hihetetlen bősége az egyik legnehezebb kérdés a betegek számára, legalábbis táplálkozás szempontjából. A legnépszerübbeket sorra is veszi a könyv, és tudományos igényességgel, objektíven ismerteti a hátteret. Legyen szó az oxigénnel dúsított vízről, a megadózisú C-vitaminról, a gombakivonatokról vagy éppen a $B_{17}$-vitaminról ésatöbbi.

\section{RECEPTEK}

A könyv második felében található a receptgyŭjtemény. A kötetre jellemző logikus tagoltság itt is érvényesül. A reggelik, levesek és feltételek, köretek és egytálételek mellett ugyanúgy helye van az italoknak, szendvicskrémeknek, sőt a nassolni valók, desszertek is képviseltetik magukat. Minden egyes recept 3 külön variációban készült el: energiaszegény, hagyományos és energiadús módon. Mindegyik verziónál megtalálható a hozzávalók mellett a kiszámolt energia- és tápanyagtartalom is.

\section{TANULSÁGOK A HAZAI SZAKEMBEREK SZÁMÁRA}

Megfelelő étrenddel, ha nem is gyógyítható a rák, de jelentősen jobb életminőség érhető el. A szerző szándéka szerint minden sorstársa talál a könyvben a maga számára olyan hasznos információt, tippet, amellyel - a lehetőségekhez képest - elviselhetőbbé tehető ez a hosszú, terápiás időszak.

A dizájn is fontos szerepet kap a kötetben, amelyet az igényes tördelés és a szép ételfotók miatt is jó érzés kézbe venni.

Információk a szerzőről:

Moharos Melinda, vállalkozó dietetikus, melinda.moharos@gmail.com 